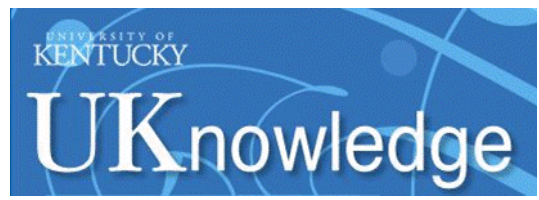

University of Kentucky

UKnowledge

Molecular and Cellular Biochemistry Faculty

Publications

Molecular and Cellular Biochemistry

3-1-2017

\title{
Epigenomic Reprogramming in Inorganic Arsenic-Mediated Gene Expression Patterns During Carcinogenesis
}

\author{
Meredith Eckstein \\ University of Kentucky, meredith.eckstein@gmail.com \\ Rebekah Eleazer \\ University of Kentucky, rebekah.eleazer@uky.edu \\ Matthew Rea \\ University of Kentucky, matthew.rea@uky.edu \\ Yvonne N. Fondufe-Mittendorf \\ University of Kentucky, y.fondufe-mittendorf@uky.edu
}

Follow this and additional works at: https://uknowledge.uky.edu/biochem_facpub

Part of the Biochemistry, Biophysics, and Structural Biology Commons, Environmental Health

Commons, Genetics and Genomics Commons, and the Inorganic Chemicals Commons

Right click to open a feedback form in a new tab to let us know how this document benefits you.

\section{Repository Citation}

Eckstein, Meredith; Eleazer, Rebekah; Rea, Matthew; and Fondufe-Mittendorf, Yvonne N., "Epigenomic Reprogramming in Inorganic Arsenic-Mediated Gene Expression Patterns During Carcinogenesis" (2017). Molecular and Cellular Biochemistry Faculty Publications. 134.

https://uknowledge.uky.edu/biochem_facpub/134

This Review is brought to you for free and open access by the Molecular and Cellular Biochemistry at UKnowledge. It has been accepted for inclusion in Molecular and Cellular Biochemistry Faculty Publications by an authorized administrator of UKnowledge. For more information, please contact UKnowledge@lsv.uky.edu. 
Epigenomic Reprogramming in Inorganic Arsenic-Mediated Gene Expression Patterns During Carcinogenesis

\section{Digital Object Identifier (DOI)}

https://doi.org/10.1515/reveh-2016-0025

Notes/Citation Information

Published in Reviews on Environmental Health, v. 32, issue 1-2, p. 93-103.

(C2016, Yvonne Fondufe-Mittendorf et al., published by De Gruyter.

This work is licensed under the Creative Commons Attribution-NonCommercial-NoDerivatives 3.0 License. 


\section{Epigenomic reprogramming in inorganic arsenic- mediated gene expression patterns during carcinogenesis}

DOI 10.1515/reveh-2016-0025

Received July 12, 2016; accepted August 8, 2016; previously published online October 4, 2016

\begin{abstract}
Arsenic is a ubiquitous metalloid that is not mutagenic but is carcinogenic. The mechanism(s) by which arsenic causes cancer remain unknown. To date, several mechanisms have been proposed, including the arsenic-induced generation of reactive oxygen species (ROS). However, it is also becoming evident that inorganic arsenic (iAs) may exert its carcinogenic effects by changing the epigenome, and thereby modifying chromatin structure and dynamics. These epigenetic changes alter the accessibility of gene regulatory factors to DNA, resulting in specific changes in gene expression both at the levels of transcription initiation and gene splicing. In this review, we discuss recent literature reports describing epigenetic changes induced by iAs exposure and the possible epigenetic mechanisms underlying these changes.
\end{abstract}

Keywords: alternative splicing; chromatin; DNA methylation; epithelial-to-mesenchymal transition; histones.

\section{Introduction}

Inorganic arsenic (iAs) is a naturally occurring toxic metalloid to which humans are routinely exposed to the environment. It is widely distributed in the earth's crust and is ubiquitous in soil, water, and air. Humans are chronically exposed to iAs through contaminated food and drinking water $(1,2)$. It is estimated that contaminated wells, formed

\footnotetext{
*Corresponding author: Yvonne Fondufe-Mittendorf, PhD, Department of Cellular and Molecular Biology, University of Kentucky, BBSRB 273 741, S. Limestone Street, Lexington, KY 40506, USA, Phone: +(859) 323-0091,

E-mail: y.fondufe-mittendorf@uky.edu; and Department of Molecular and Cellular Biochemistry, University of Kentucky, Lexington, KY 40536, USA

Meredith Eckstein, Rebekah Eleazer and Matthew Rea: Department of Molecular and Cellular Biochemistry, University of Kentucky, Lexington, KY, USA
}

from proximity to iAs-rich geological formations, expose 160 million individuals worldwide to excessive levels of iAs (1) which is over the US environmental protection agency's guideline of $10 \mathrm{ppb}$ (3). The long-term effects of low-dose iAs exposure from contaminated drinking water continue as mining efforts, which release high amounts of iAs into the groundwater, persist in many regions of the world $(1,4)$. While not genotoxic, arsenic and iAs compounds are listed as known human carcinogens by the National Toxicology Program (2). Epidemiological studies demonstrate a strong relationship between environmental iAs exposure and an increased cancer incidence. Such exposure correlates with an increased risk of lymphatic (5), hemtatopoietic (6), skin, lung (5-7), digestive tract (5), liver (6), urinary tract $(6,8,9)$, and prostate $(5,6)$ cancers. Although the precise mechanisms by which iAs causes cancer remain elusive, several mechanisms have been proposed. These mechanisms include iAs-induced oxidative stress, inhibition of DNA repair, micronuclei formation, chromosomal aberrations, and changes to the epigenome. This review will focus on proposed epigenetic mechanisms that contribute to iAs-induced carcinogenesis; however iAs generally, might be effecting similar epigenetic mechanisms during pathogenesis.

\section{Proposed mechanisms of iAs-mediated carcinogenesis and toxicity}

A variety of mechanisms may contribute to the carcinogenicity caused by iAs. One mechanism involves the iAs-induced production of reactive oxygen species (ROS) which has been reported in multiple cell models including human lung bronchial epithelial BEAS-2B cells, human vascular smooth muscle cells, vascular endothelial cells, U937 cells, NB4 cells, human-hamster hybrid cells, CHO-K1 cells, and HEL30 cells (10-16). The impact of iAs on ROS production is hypothesized to occur in two steps. First, 
iAs initiates production of high ROS levels, which chemically react with DNA. This reaction damages the DNA and disrupts its structural integrity; thus, contributing to cellular transformation and tumor proliferation (17). NADPH oxidase (NOX) has been implicated as the primary source for the generation of $\mathrm{O}_{2}(18,19)$. Though iAs is not able to induce the expressions of $\mathrm{p} 47, \mathrm{p} 67, \mathrm{p} 91$, and several scaffolding proteins of the NOX complex, it is, however, able to stimulate enzyme activity of NOX by inducing the phosphorylation and translocation of p47 $(18,20)$. Second, cells react to the increased amounts of ROS by overexpressing the antioxidant enzymes superoxide dismutase, catalase, and glutathione, which protect cells against apoptosis. The decreased apoptosis and accumulation of damaged cells increases carcinogenic potential (17).

Chromosomal instability and epigenetic modifications may also play roles in the carcinogenicity of iAs. At low doses, iAs does not cause DNA base pair mutations; instead, it is known to generate double-stranded breaks (21), which results in large-scale chromosomal aberrations (22). Interestingly, iAs exposure results in the impairment of proteins involved in base excision repair such as apurinic/apyrimidinic (abasic) endonuclease (APEX1), DNA ligase 1 (LIG1), DNA ligase 3 (LIG3), oxo-guanine glycosylase (OGG1), poly(ADP) ribose polymerase (PARP1), and DNA polymerase $\beta$ (POLB) [reviewed in (23)]. The iAs-mediated chromosomal instability occurs frequently at centromeres, leading to the formation of acentric chromosomes or the fusion of centromeres between two chromosomes (24). Fusion of two chromosomes at their centromeres can cause improper chromosome segregation, which results in aneuploidy or in micronuclei formation $(21,25)$. However, a fusion that occurs at chromosomal ends may result in the formation of ring-like structures and/or participate in abnormal sister chromatid exchanges $(24,26)$; both of which are deleterious to the cell. While these are large-scale chromosomal rearrangements, iAs also effects changes to chromatin structure at the nucleosome level; these changes alter local chromatin conformation that ultimately fine-tune the iAsmediated gene expression profile.

Eukaryotic DNA is packaged in the form of chromatin, which has a basic repeating unit, the nucleosome. Each nucleosome consists of 147 DNA base pairs wrapped around two molecules each of four canonical histones (histones H2A, H2B, H3, and H4). The tails of these histones are subject to a variety of post-translational modifications (PTMs) $(27,28)$, which are dynamically regulated to control the accessibility of chromatin to factors that direct gene expression. Histone PTMs, other epigenetic marks (e.g. methylated DNA or distinctly-combined histone variants), and microRNAs (miRNAs) are collectively known as epigenetic regulators. The remainder of this review will focus on the most recent studies that investigate the role of iAs exposure in reprogramming these epigenetic marks, and how this reprogramming may mediate iAs toxicity.

\section{DNA methylation}

DNA methylation is one of the several epigenetic mechanisms that cells use to control gene expression. The effect of DNA methylation on a gene's expression depends on the type of regulatory element at which the methylation occurs. For instance, methylation of a promoter is associated with gene repression. However, methylation within the gene body is generally associated with gene expression and splice regulation, although the latter processes are poorly understood.

The results of several studies have implicated aberrant DNA methylation in many cancers but our understanding of the impact of iAs on DNA methylation is just emerging (29-31). For instance, Zhao et al. showed that chronic, low-dose exposure of cells to iAs for 18 weeks caused global hypomethylation. Other studies revealed that iAs exposure to human skin led to global hypomethylation of some tissues (leukocytes), and iAs exposure in rodent liver instigated hypomethylation $(32,33)$. However, other research indicates that iAs exposure leads to hypermethylation at the promoters of specific tumor-suppressor genes, resulting in their repression $(34,35)$. For example, in iAs-exposed human hepatocytes, significant hypermethylation of the promoters for genes involved in DNA repair such as excision repair cross-complementation group 2 (ERCC2) and replication protein A1 (RPA1), and of genes associated with the Wnt pathway like c-MYC (MYC) and Wnt family member 2B (WNT2B), were observed (34). Additionally, significant hypermethylation of the promoters for the tumor suppressor p16 $(36,37)$, and the DNA repair gene, mutL homolog 1 (MLH1) (36), were observed in whole blood obtained from humans chronically exposed to iAs. Conversely, iAs-induced hypomethylation of promoters for genes involved in processes such as endocytosis and RNA transport were also observed (34). Interestingly, another study involving chronic exposure of a human population to arsenic demonstrated hypomethylation at the promoter of the DNA repair gene, ERCC2 (38).

While these findings may at first seem incongruous, it is now clear that, although global hypomethylation occurs, modifications at specific genetic loci can also be either hypo or hypermethylated. Furthermore, it is possible that some of these disparities may be explained by the use of different model systems, different stages of 
malignant transformation, and different experimental conditions (e.g. the dose of iAs, the duration of iAs exposure, and the presence or absence of other carcinogens). For instance, Pilser et al. suggested that folate can influence iAs-mediated DNA methylation profiles in peripheral blood leukocytes taken from Bangladeshi adults (33). Overall, though, these studies suggest that iAs-mediated malignant transformations result from multiple changes in DNA methylation patterns and that these altered patterns can have positive or negative effects on the expression of specific genes. One should be cautious when drawing general conclusions about observed iAs-induced changes in DNA methylation patterns from any one study. Most importantly, profiling should be performed together with analyses of the functional consequences of such changes in DNA methylation.

Researchers have proposed several possible mechanisms for iAs-mediated changes in DNA methylation. In humans, DNA methylation is initiated by the de novo DNA methyltransferase 3 (DNMT3A and B) and maintained by DNA methyltransferase 1 (DNMT1) (39). Following low-dose iAs exposure, the expression of the DNMTs is reduced, which results in less methylation at target sites (40-42). Because DNMTs also participate in DNA repair, inactivation and/or reduction in the expression levels of DNA methyltransferases will also impede DNA repair efficiency $(35,41,43,44)$. Another possible explanation for iAs-mediated alterations in DNA methylation involves the depletion of methyl groups. When cells metabolize arsenic, the arsenic methyltransferase, AS3MT, transfers a methyl group from S-adenosylmethionine (SAM) to the arsenite (34), depleting the available methyl groups needed by the DNMTs for DNA methylation (41). This competition for methyl groups affects DNA methylation supported by DNMTs, but also the histone methyltransferases. As the name implies, these enzymes methylate histones and, likewise, are important components of epigenetic regulation. Interestingly, there is interplay between DNA methylation and histone modification; thus, an imbalance in one epigenetic mark could also trigger other epigenetic changes at specific gene regulatory regions.

\section{Histone modifications}

PTMs of the N-terminal tails of histone proteins change the chromatin structurally and functionally, thereby altering gene expression. Histone PTMs include methylation, acetylation, phosphorylation, glycosylation, carbonylation, ubiquitylation, biotinylation, sumoylation, citrullination, ADP-ribosylation, $\mathrm{N}$-formylation, crotonylation, propionylation, and butyrylation, as well as proline and aspartic acid isomerization. The sum of all of these histone PTMs is known as the histone code (45). Histone PTMs permit, increase or restrict access to chromatin by gene regulatory factors. Among the many that have been identified, the most extensively studied and best-understood histone PTMs in the context of transcriptional competency are phosphorylation, methylation, acetylation, and ubiquitination (46).

Several in vitro studies have demonstrated that iAs exposure can result in global changes in histone PTMs. These changes include increases in H3K9me2, H3K4me3, and $\mathrm{H} 3 \mathrm{~S} 10$, decreases in $\mathrm{H} 2 \mathrm{~B}$ ubiquitination, and either increases or decreases in H3K27me3 (47-52). In addition, following iAs exposure in humans, blood cells exhibited an overall decrease in H3K9me3 and H3K9ac, with an increase in H3K9me2 $(47,48)$. Interestingly, these studies also showed that the iAs-induced changes in histone PTMs can be gender-specific. For instance, a decrease in H3K27ac and H3K18ac and increase in H3K4me3 and H3K27me3 was observed in iAs-exposed females, while the inverse trend was observed in iAs-exposed males (47).

The majority of PTMs that affect chromatin accessibility are modifications to histone H3 (e.g. H3K4, H3K9, H3K27, and H3K36). Methylation of H3K4 is performed by a series of type 2 lysine methyltransferases (KMT2) (53) and occurs in a stepwise manner; methylation proceeds from the mono- to the di- and, finally, to the tri-methylation state. These different H3K4me states vary in their genomic distributions: H3K4me1 occurs at the 3' end of genes, H3K4me2 occurs within the gene body, and H3K4me3 occurs at gene promoters (53). Deposition of H3K4me3 at gene promoters and coding regions correlates with transcriptional activation $(50,54,55)$. Exposure of cells to iAs results in a global decrease in monomethylated H3K4, with a corresponding increase in H3K4's di- and tri-methylated states (50). This shift in the global H3K4 methylation status occurs quickly; exposing cells to $1 \mu \mathrm{M}$ iAs led to the changes in H3K4 methylation states in as little as $24 \mathrm{~h}$ (50). Furthermore, Tyler et al. found that perinatal arsenic exposure resulted in changes to H3K9Ac and H3K4me3 levels in the brains of adult mice $(56,57)$.

Analogous to H3K4 methylation, H3K9 is first monomethylated and then dimethylated by euchromatic histone-lysine N-methyltransferase 2 (KMT1C, also known as G9a). Suppressor of variegation 3-9 homolog 1 (KMT1A, also known as SUV39h1) then converts the di-methylated state further to the tri-methylated state by $(49,58)$. These methylation events are offset by lysine demethylase $3 \mathrm{~A}$ (KDM3A), a histone demethylase that reverses the monoor di-methylation of $\mathrm{H} 3 \mathrm{~K} 9$ (49). Like methylated H3K4, the 
di- and tri-methylated states of $\mathrm{H} 3 \mathrm{~K} 9$ are typically found in different chromatin locations; H3K9me2 tends to localize at the edges of the nucleus, where heterochromatin is more common, while H3K9me3 is found in the center of the nucleus, where euchromatin predominates $(49,50)$. Exposure of A549 lung carcinoma cells to iAs increased expression of KMT1C, leading to an increase in H3K9me2 and H3K9me3 levels (49). Furthermore, Chervona et al. observed a variety of correlations between iAs exposure and this type of modification in peripheral blood mononuclear cells using a population-based study in Bangladesh. This study further revealed a positive correlation between urinary iAs and H3K9me2 $(47,59)$.

H3K27 methylation is another important PTM for histone H3. This repressive PTM is mediated by the polycomb repressive complex 2 (PRC2); PRC2 is composed of three core components: Enhancer of Zeste 1 or 2 (EZH1/2), suppressor of Zeste 12 (SUZ12), and embryonic ectodermal development (EED). The methylation state conferred by PRC2 is determined by the homolog of EZH present in the complex - EZH1 mediates the monomethylation of H3K27, while EZH2 mediates its di- and tri-methylation. H3K27me3 is associated with inactive promoters and gene silencing and, importantly, it marks chromatin for further compaction by protein regulator of cytokinesis (PRC1) via ubiquitylation of H2AK119 (60). The iAs exposure greatly increases the expression of the EZH2 homolog and of other PRC2 core components, resulting in a global increase in H3K27me3 levels (51). A persistent increase in $\mathrm{EZH} 2$ and the subsequent incorporation of $\mathrm{H} 3 \mathrm{~K} 27 \mathrm{me} 3$ into chromatin silences the promoters of target genes, which is enhanced by the crosstalk that occurs between epigenetic marks. A clear example of this cross-talk is seen by the reduced expressions of p19ARF and p16INK4a due to the incorporation of H3K27me3 and H3K9me2, and to the methylation of DNA at the INK4/ARF regulatory locus in iAs-exposed cells $(37,61,62)$.

It is well known that many changes in histone marks are mediated by histone kinases. The kinase-mediated phosphorylation of histone $\mathrm{H} 3$ is one example that is associated with cell proliferation and transformation (63, 64). With regard to arsenic exposure, it is likely that iAs activates a cell signaling pathway that modifies histones. For example, iAs induces the activation of the nuclear mitogen and stress-activated protein kinase 1 (MSK1) via the p38 MAPK pathway $(29,65)$, and this process was necessary for iAs-induced transformation (66). Interestingly, in response to stress, MSK1 phosphorylates KDM3A (p-KDM3A) at Ser264, resulting in the enrichment and recruitment of signal transducer and activator of transcription 1 (STAT-1) and p-KDM3A to target gene promoters.
These events promote the localized demethylation of H3K9 with consequential increased transcriptional activity (67). Additionally, MSK1 can directly phosphorylate H3S10 (68, 69), which recruits scaffolding proteins to the promoters of immediate-early genes, including those of protooncogenes FOS and JUN, to induce their activation (70).

Only a few studies have demonstrated a connection between histone phosphorylation and arsenic-induced carcinogenicity. Studies have suggested that arsenicinduced $\mathrm{H} 3$ phosphorylation might be responsible for the up-regulation of the oncogenes c-fos and c-jun (65). Most recently, Ray et al. reported that iAs induces a coordinated regulation of Nrf2 and histone H3S10 phosphorylation, which activates the human heme oxygenase- 1 gene (HMOX1) (52). These results reinforce the notion that iAs modulates gene expression by operating through the JNK and $\mathrm{p} 38 / \mathrm{Mpk} 2$ kinase pathway to promote cancer.

The iAs may also modulate histone PTMs by activating the epidermal growth factor (EGF) pathway (71). Upon activation of this pathway, pyruvate kinase, muscle 2 (PKM2) a histone kinase - translocates to the nucleus, where it binds and phosphorylates Thr11 on histone H3 (H3T11). This phosphorylation not only accelerates the demethylation of H3K9me3 by the trimethylation-specific H3 methylase KDM4C but also leads to the dissociation of HDAC3, allowing the acetylation of $\mathrm{H} 3$ with subsequent transcription of oncogenes MYC and cyclin D1 (CCND1) (72). By influencing this pathway, iAs may indirectly control the phosphorylation and acetylation state of histones, and therefore the expression patterns of target genes.

\section{Histone variants}

In addition to the four canonical histones, there are also highly conserved variants of these histones. The variants differ by only a few amino acids, and their expression is generally lower than the canonical histones. Each histone variant has a specific gene expression, and a distinct chromatin localization/incorporation that confers, within the chromatin structure, information specifying the cell-type, the stage of differentiation and tissue. However, compared to the canonical histones, studies on histone variants are limited, and so the role these chromatin-incorporated histone variants play in normal cells and even in diseased states is only beginning to emerge. Our understanding of the impact these histone variants have on chromatin biology is hindered by a lack of high-resolution and sensitive assays to differentiate these proteins, as they have a very similar amino acid composition to canonical histones. However, using high-resolution Top-down mass 
spectrometry, recent studies from our laboratory showed that some histone variants were dynamically altered during iAs-mediated malignant transformation. Specifically, we showed that histone H2B variants were abnormally expressed following iAs exposure, and during the subsequent iAs-mediated epithelial-mesenchymal transition (EMT) (73). We identified a total of $16 \mathrm{H} 2 \mathrm{~B}$ variants, 13 somatic and three testis-specific; of the somatic variants, seven were upregulated while three were downregulated (73-77). The most significant changes observed in our study were the upregulation of histones H2B1K and H2B1C, and downregulation of histones H2B1D and H2B1B. The results demonstrated that although histones are highly conserved, changes in single amino acids can influence chromatin dynamics that lead to transcriptional reprogramming critical for cell-type specificity and differentiation (77). Interestingly, removal of iAs returned expression levels for some variants to normal levels while others remained abnormal, suggesting that some epigenetic changes are transient (73). This iAs removal and its associated reversed gene expression, correlated with a reversal in the variant histones expressed during EMT. Therefore, it is possible that the carcinogenic potential seen in these cells is driven by expression patterns of histone variants that did not revert following iAs removal.

The iAs is known to disrupt the balance between canonical histone H3.1 and variant histone H3.3. Histone H3.1 transcription levels are highest during $S$ phase, while H3.3 expression levels are consistently low throughout the cell cycle (78-83). Functionally, histone H3.1 is ubiquitously present in genomic chromatin, while histone H3.3 is incorporated into DNA promoter regions to specifically facilitate transcriptional activation $(84,85)$. The iAs treatment increases histone $\mathrm{H} 3.1$ stability, hindering the interaction of histone H3.3 with chromatin and changed nucleosome composition; these effects likely change the gene expression patterns (86). Specifically, the irregular incorporation of $\mathrm{H} 3.1$ could silence tumor-suppressor genes and abnormally activate cell-cycle genes. The proposed mechanism for this iAs-mediated increased influence by $\mathrm{H} 3.1$ involves an associated inhibition of stem-loop binding protein (SLBP) expression $(87,88$ ). Under normal conditions, SLBP binds to the stem-loop on histone transcripts preventing their degradation. With iAs exposure, SLBP expression levels are reduced allowing more proteasomal degradation of the protein $(80,86)$. With less SLBP present, canonical histone transcripts with the stem loop are degraded, leaving those with a polyadenylated tail (H3.1) intact. Indeed, the addition of a poly(A) tail to histone transcripts increases their stability so they may be present in higher levels outside of
S phase. This processing ultimately increases H3.1 levels and blocks potential histone $\mathrm{H} 3.3$ interactions at strategic sites, causing aberrant gene expression (86). Knockdown of SLBP caused increased cell growth and transformation, indicating that this mechanism may be implicated in arsenic-induced carcinogenesis (86).

Other histone variants are implicated in carcinogenesis. For example, abnormal expression of histone H2A.X, a histone variant involved in double-stranded break repair, genome stability, and tumor suppression (89-93) has been associated with progression of EMT in colon and lung cancer $(94,95)$. When histone H2A.X levels are reduced, the variant is removed from the gene loci for Slug and ZEB1 (EMT markers) creating a relaxed chromatin structure and increased expression (94). Upregulation of histone H2A.Z, another histone H2A variant, is implicated in colorectal and breast cancer (96-100). Histone H2A.Z normally maintains the stability and integrity of the genetic material within the cell $(101,102)$. When this variant is upregulated, cell growth and proliferation increase by an activation of cell cycle regulators and EMT markers such as E-cadherin and fibronectin $(94,96,103)$. Yet another set of histone H2A isoforms, H2A.1 and H2A.2, are repressive and reduce tumorogenesis (104). These histone variants typically act as tumor suppressors by hindering the efficiency of transcription factor binding and chromatin remodeling at strategic sites (105-108). Finally, upregulation of CENP-A, a centromere-specific H3-like histone, is thought to increase the incidence of aneuploidy and dysregulation of cell cycle-associated genes, and also is implicated in cancer (109). Further research is needed to determine if iAs-induced carcinogenesis and toxicity employ any of these cancer-related histone variants.

\section{MicroRNAs}

MicroRNAs (miRNAs) constitute another epigenetic mechanism of gene regulation affecting development, growth, and the response to stress. Several in vitro and human studies demonstrated arsenic-induced alterations in miRNA gene expression. For instance, Marsit et al. showed global increases in miRNA expression in response to iAs exposure (110). In addition, miR-222 and miR-21 expressions were increased in the peripheral blood of steel factory workers (111). In contrast, a study of Hong Kong children aged 12-19 years, found decreased expression of both miR-21 and miR-221 associated with increased urinary arsenic and lead levels (112). Furthermore, in a pregnancy cohort from Mexico, maternal total urinary iAs was associated with the increased expression of 12 miRNAs 
in infant cord blood. This study utilized genome-wide miRNA analysis and suggests that miRNA alterations can lead to gene expression changes in progeny (113). Using transcriptome-wide next generation sequencing, Yu et al. identified expression changes for 36 new miRNAs from iAs-tainted rice (114). Another study in plants showed that iAs altered the expression of miR167, miR319, and miR854 (115). Investigations have pursued the function and potential mechanism of these microRNAs in iAs toxicity. For example, upregulation of microRNA-21 can enhance the transformation potential of a cell by targeting programmed cell-death 4 (PDCD4) (116). Another functional mechanism identified is the iAs-mediated transformation in p53 (low) HBECs, which can be reversed by zinc finger E-box binding homeobox 1 (ZEB1 and ZEB2)-mediated increases in the levels microRNA 200b. Also identified, iAs-mediated autophagy is supported by microRNA-21-induced PTEN-ERK signaling, and iAs-induced angiogenesis occurs through a microRNA425-5p-regulated CCM3 (117). With the help of new technology, additional iAs-associated miRNAs functions and processes will be discovered, revealing the regulatory network that mediates iAs toxicity and carcinogenesis.

\section{Alternative splicing}

Epigenetic regulation of gene expression occurs at the level of transcriptional activation, as discussed above, but also through the less investigated process of splicing. Alternative splicing (AS) of pre-mRNA occurs in the majority of multi-exon genes and greatly increases the diversity of the proteome. Aberrant splicing is known to occur in human cancers (118-120), and a proposed mechanism is the substitutions of isoforms associated with carcinogenesis (121), angiogenesis (122), and EMT (123, 124). Epigenetic modifications are thought to regulate AS by two non-mutually exclusive means: 1 ) by affecting the kinetics of polymerase elongation and 2) through recruitment of splicing regulatory factors. Two types of epigenetic marks, DNA methylation (125-128) and histone PTMs (120, 129-132), have been implicated in the selection of exoncandidates. Exposure to iAs significantly alters DNA methylation (133) and histone PTMs (48-50, 62, 134-136), and so it is reasonable to expect that this exposure can induce changes in alternative splicing. Indeed, we recently showed that low-dose iAs exposure results in changes in AS (133), though the mechanism remains unknown.

One possible mechanism by which iAs influences AS may be through an inhibition of DNA binding by alternative splicing regulators such as CCCTC-binding factor (CTCF) and poly (ADP) ribose polymerase (PARP1) $(132,137,138)$. Interestingly, PARP1 co-localizes with CTCF on chromatin; this complex, with CTCF-dependent automodification of PARP1, permits PARylation activity in the absence of DNA damage $(137,139)$. Importantly, many splicing factors are regulated by PARylation (140-144) and any iAs-mediated inhibition of PARP1 binding to DNA not only affects the structural properties of chromatin but also the PARylation activities, which indirectly affect splicing decisions. In addition, the binding of proteins to DNA can be altered by the presence of iAs due to the high binding affinity of this metalloid for cysteine residues that are found in $\mathrm{C} 4$ and $\mathrm{C} 3 \mathrm{H} 1$ zinc finger motif-containing proteins such as PARP1 (145-147). Other DNA-binding proteins with zinc finger motifs inhibited by iAs are the methylcytosine dioxygenases (TET1/2), needed to oxidize 5-methylcytosine to 5-hydroxymethylcytosine and 5-carboxylcytosine (148). Inactivation of TET1/2 by iAs allows 5-methylcytosine to accumulate at CTCF target sites and prevents CTCF from binding to its target sites, resulting in exon exclusion (126). In summary, if iAs blocks the binding of PARP1 or CTCF to DNA, the chromatin-associated functioning of these proteins is altered, which includes splicing decisions.

A second possible mechanism by which iAs may alter AS is by increasing the presence of $\mathrm{p} 52$ through activation of the non-canonical NF- $\mathrm{KB}$ pathway (149). P52 co-localizes and interacts with the splicing factor SRSF1 to modulate splicing (129). The role of SRSF1 in carcinogenesis is well studied (150), and its expression is upregulated by MYC (151), which in itself is deregulated in iAs exposure $(34,152)$. MYC also directly upregulates core pre-mRNA machinery during carcinogenesis and maintains appropriate splicing of alternative exons (153).

The dominant isoform expressed for any given gene is tissue-specific and may result from differentially expressed splicing regulatory factors among tissue types (154-156). As changes in AS are likely to vary from tissue to tissue, our ability to dissect and understand the complicated issue of what drives iAs-mediated carcinogenesis is exacerbated.

\section{Conclusion}

A large body of research has implicated low-dose arsenic exposure in carcinogenesis and EMT. This review examines the impact of epigenetic processes, including DNA methylation, histone PTMs, histone variants, and alternative splicing, on carcinogenesis mediated through iAs 
exposure. While all of these epigenetic marks are associated with iAs-induced carcinogenesis, additional research is required to clarify the mechanism(s) driving each system. Expanded research in this area will delineate the role of iAs exposure in the initiation and development of cancer. Finally, while this review is on arsenic, it is possible that other heavy metals act through similar epigenetic mechanisms. However, a comprehensive genome-wide analysis comparing the effects of toxic metals in a single study will help delineate whether similar epigenetic mechanisms are targeted by heavy metals.

\section{References}

1. IARC. Some drinking-water disinfectants and contaminants, including arsenic. IARC Monogr Eval Carcinog Risks Hum 2004;84:39-267.

2. NTP (National Toxicology Program). Report on Carcinogens, 13th ed. Research Triangle Park, NC: U.S. Department of Health and Human Services, Public Health Service; 2014. http://ntp. niehs.nih.gov/pubhealth/roc/roc13/.

3. Rahman MM, Ng JC, Naidu R. Chronic exposure of arsenic via drinking water and its adverse health impacts on humans. Environ Geochem Health 2009;Suppl 1:189-200. doi: 10.1007/s10653-008-9235-0.

4. Nordstrom DK. Public health. Worldwide occurrences of arsenic in ground water. Science 2002;296:2143-5.

5. Nunez O, Fernandez-Navarro P, Martin-Mendez I, Bel-Lan A, Locutura JF, et al. Arsenic and chromium topsoil levels and cancer mortality in Spain. Environ Sci Pollut Res Int 2016;23:17664-75.

6. Garcia-Esquinas E, Pollan M, Umans JG, Francesconi KA, Goessler W, et al. Arsenic exposure and cancer mortality in a US-based prospective cohort: the strong heart study. Cancer Epidemiol Biomarkers Prev 2013;22:1944-53.

7. Celik I, Gallicchio L, Boyd K, Lam TK, Matanoski G, et al. Arsenic in drinking water and lung cancer: a systematic review. Environ Res 2008;108:48-55.

8. Baris D, Waddell R, Beane Freeman LE, Schwenn M, Colt JS, et al. Elevated bladder cancer in Northern New England: the role of drinking water and arsenic. J Natl Cancer Inst 2016;108:1-9.

9. Saint-Jacques N, Parker L, Brown P, Dummer TJ. Arsenic in drinking water and urinary tract cancers: a systematic review of 30 years of epidemiological evidence. Environ Health 2014;13:44.

10. Lynn S, Gurr JR, Lai HT, Jan KY. NADH oxidase activation is involved in arsenite-induced oxidative DNA damage in human vascular smooth muscle cells. Circ Res 2000;86:514-9.

11. Liu SX, Athar M, Lippai I, Waldren C, Hei TK. Induction of oxyradicals by arsenic: implication for mechanism of genotoxicity. Proc Natl Acad Sci USA 2001;98:1643-1648.

12. Iwama K, Nakajo S, Aiuchi T, Nakaya K. Apoptosis induced by arsenic trioxide in leukemia U937 cells is dependent on activation of p38, inactivation of ERK and the Ca2+-dependent production of superoxide. Int J Cancer 2001;92:518-26.

13. Barchowsky A, Klei LR, Dudek EJ, Swartz HM, James PE. Stimulation of reactive oxygen, but not reactive nitrogen species, in vascular endothelial cells exposed to low levels of arsenite. Free Radic Biol Med 1999;27:1405-12.
14. Jing Y, Dai J, Chalmers-Redman RM, Tatton WG, Waxman S. Arsenic trioxide selectively induces acute promyelocytic leukemia cell apoptosis via a hydrogen peroxide-dependent pathway. Blood 1999;94:2102-11.

15. Corsini E, Asti L, Viviani B, Marinovich M, Galli CL. Sodium arsenate induces overproduction of interleukin-1alpha in murine keratinocytes: role of mitochondria. J Invest Dermatol 1999;113:760-5.

16. Chang Q, Pan J, Wang X, Zhang Z, Chen F, et al. Reduced reactive oxygen species-generating capacity contributes to the enhanced cell growth of arsenic-transformed epithelial cells. Cancer Res 2010;70:5127-35.

17. Zhang Z, Pratheeshkumar P, Son Y-O, Kim D, Shi X. Role of reactive oxygen species in arsenic-induced transformation of human lung bronchial epithelial (BEAS-2B) cells. Biochem Bioph Res Commun 2015;456:643-8.

18. Chou WC, Jie C, Kenedy AA, Jones RJ, Trush MA, et al. Role of NADPH oxidase in arsenic-induced reactive oxygen species formation and cytotoxicity in myeloid leukemia cells. Proc Natl Acad Sci U S A 2004;101:4578-83.

19. Straub AC, Clark KA, Ross MA, Chandra AG, Li S, et al. Arsenic-stimulated liver sinusoidal capillarization in mice requires NADPH oxidase-generated superoxide. J Clin Invest 2008;118:3980-9.

20. Lemarie A, Bourdonnay E, Morzadec C, Fardel O, Vernhet L. Inorganic arsenic activates reduced NADPH oxidase in human primary macrophages through a Rho Kinase/p38 Kinase pathway. J Immunol 2008;180:6010-7.

21. Xie H, Huang S, Martin S, Wise Sr JP. Arsenic is cytotoxic and genotoxic to primary human lung cells. Mutat Res-Gen Toxicol Environ Mutatgen 2014;760:33-41.

22. Klein CB, Leszczynska J, Hickey C, Rossman TG. Further evidence against a direct genotoxic mode of action for arsenic-induced cancer. Toxicol Appl Pharm 2007;222:289-97.

23. Muenyi C, Ljungman M, States J. Arsenic disruption of DNA damage responses - potential role in carcinogenesis and chemotherapy. Biomolecules 2015;5:2184.

24. Kesari VP, Kumar A, Khan PK. Genotoxic potential of arsenic at its reference dose. Ecotox Environ Safe 2012;80:126-31.

25. Warner ML, Moore LE, Smith MT, Kalman DA, Fanning E, et al. Increased micronuclei in exfoliated bladder cells of individuals who chronically ingest arsenic-contaminated water in Nevada. Cancer Epidemiol Biomarkers Prev 1994;3:583-90.

26. Zanzoni F, Jung EG. Arsenic elevates the sister chromatid exchange (SCE) rate in human lymphocytes in vitro. Arch Dermatol Res 1980;267:91-5.

27. Bannister AJ, Kouzarides T. Regulation of chromatin by histone modifications. Cell Res 2011;21:381-95.

28. Strahl BD, Allis CD. The language of covalent histone modifications. Nature 2000;403:41-5.

29. Kannan-Thulasiraman P, Katsoulidis E, Tallman MS, Arthur JS, Platanias LC. Activation of the mitogen- and stress-activated kinase 1 by arsenic trioxide. J Biol Chem 2006;281:22446-52.

30. Giacinti L, Claudio PP, Lopez M, Giordano A. Epigenetic Information and Estrogen Receptor Alpha Expression in Breast Cancer. Oncologist 2006;11:1-8.

31. Robertson KD, Wolffe AP. DNA methylation in health and disease. Nat Rev Genet 2000;1:11-9.

32. Chen H, Li S, Liu J, Diwan BA, Barrett JC, et al. Chronic inorganic arsenic exposure induces hepatic global and individual gene 
hypomethylation: implications for arsenic hepatocarcinogenesis. Carcinogenesis 2004;25:1779-86.

33. Pilsner JR, Liu X, Ahsan H, Ilievski V, Slavkovich V, et al. Folate deficiency, hyperhomocysteinemia, low urinary creatinine, and hypomethylation of leukocyte DNA are risk factors for arsenicinduced skin lesions. Environ Health Perspect 2009;117:254-60.

34. Miao Z, Wu L, Lu M, Meng X, Gao B, et al. Analysis of the transcriptional regulation of cancer-related genes by aberrant DNA methylation of the cis-regulation sites in the promoter region during hepatocyte carcinogenesis caused by arsenic. Oncotarget 2015;6:21493-506.

35. Zhao CQ, Young MR, Diwan BA, Coogan TP, Waalkes MP. Association of arsenic-induced malignant transformation with DNA hypomethylation and aberrant gene expression. Proc Natl Acad Sci USA 1997;94:10907-12.

36. Hossain MB, Vahter M, Concha G, Broberg K. Environmental arsenic exposure and DNA methylation of the tumor suppressor gene p16 and the DNA repair gene MLH1: effect of arsenic metabolism and genotype. Metallomics 2012;4:1167-75.

37. Lu G, Xu H, Chang D, Wu Z, Yao X, et al. Arsenic exposure is associated with DNA hypermethylation of the tumor suppressor gene p16. J Occup Med Toxicol 2014;9:42.

38. Paul S, Banerjee N, Chatterjee A, Sau TJ, Das JK, et al. Arsenicinduced promoter hypomethylation and over-expression of ERCC2 reduces DNA repair capacity in humans by non-disjunction of the ERCC2-Cdk7 complex. Metallomics 2014;6:864-73.

39. Bestor TH. The DNA methyltransferases of mammals. Human Mol Genet 2000;9:2395-402.

40. Cheng T-F, Choudhuri S, Muldoon-Jacobs K. Epigenetic targets of some toxicologically relevant metals: a review of the literature. J Appl Toxicol 2012;32:643-53.

41. Reichard JF, Schnekenburger M, Puga A. Long term low-dose arsenic exposure induces loss of DNA methylation. Biochem Bioph Res Commun 2007;325:188-92.

42. Treas JN, Tyagi T, Singh KP. Effects of chronic exposure to arsenic and estrogen on epigenetic regulatory genes expression and epigenetic code in human prostate epithelial cells. PLoS One 2012;7:e43880. doi: 10.1371/journal.pone.0043880.

43. Wang K-Y, James Shen CK. DNA methyltransferase Dnmt1 and mismatch repair. Oncogene 2004;23:7898-902.

44. Bach J, Peremartí J, Annangi B, Marcos R, Hernández A. Reduced cellular DNA repair capacity after environmentally relevant arsenic exposure. Influence of Ogg1 deficiency. Mutat Res 2015;779:144-51.

45. Gardner KE, Allis CD, Strahl BD. OPERating ON chromatin, a colorful language where context matters. J Mol Biol 2011;409:36-46.

46. Peterson CL, Laniel MA. Histones and histone modifications. Curr Biol 2004;14:R546-51.

47. Chervona Y, Hall MN, Arita A, Wu F, Sun H, et al. Associations between arsenic exposure and global posttranslational histone modifications among adults in Bangladesh. Cancer Epidemiol Biomarkers Prev 2012;21:2252-60.

48. Pournara A, Kippler M, Holmlund T, Ceder R, Grafstrom R, et al. Arsenic alters global histone modifications in lymphocytes in vitro and in vivo. Cell Biol Toxicol 2016;32:275-84.

49. Zhou X, Sun H, Ellen TP, Chen H, Costa M. Arsenite alters global histone H3 methylation. Carcinogenesis 2008;29:1831-6.

50. Zhou X, Li Q, Arita A, Sun H, Costa M. Effects of nickel, chromate, and arsenite on histone 3 lysine methylation. Toxicol Appl pharm 2009;236:78-84.
51. Kim H-G, Kim D, Li S, Lee K, Li X, et al. Polycomb (PcG) Proteins, BMI1 and SUZ12, Regulate Arsenic-induced Cell Transformation. J Biol Chem 2012;287:31920-8.

52. Ray PD, Huang BW, Tsuji Y. Coordinated regulation of Nrf2 and histone $\mathrm{H} 3$ serine 10 phosphorylation in arsenite-activated transcription of the human heme oxygenase-1 gene. Biochim Biophys Acta 2015;1849:1277-88.

53. Kusch T. Histone H3 lysine 4 methylation revisited. Transcription 2012;3:310-4.

54. Guillemette B, Drogaris P, Lin HH, Armstrong H, Hiragami-Hamada $\mathrm{K}$, et al. $\mathrm{H} 3$ lysine 4 is acetylated at active gene promoters and is regulated by $\mathrm{H} 3$ lysine 4 methylation. PLoS Genet 2011; 7:e1001354.

55. Ruthenburg AJ, Allis CD, Wysocka J. Methylation of lysine 4 on histone $\mathrm{H} 3$ : intricacy of writing and reading a single epigenetic mark. Mol Cell 2007;25:15-30.

56. Tyler CR, Weber JA, Labrecque M, Hessinger JM, Edwards JS, et al. ChIP-Seq analysis of the adult male mouse brain after developmental exposure to arsenic. Data Brief 2015;5:248-54.

57. Tyler CR, Hafez AK, Solomon ER, Allan AM. Developmental exposure to 50 parts-per-billion arsenic influences histone modifications and associated epigenetic machinery in a regionand sex-specific manner in the adult mouse brain. Toxicol Appl Pharmacol 2015;288:40-51.

58. Lin Y, Dong C, Zhou BP. Epigenetic regulation of EMT: the Snail story. Curr Pharm Des 2014;20:1698-705.

59. Chervona Y, Arita A, Costa M. Carcinogenic metals and the epigenome: understanding the effect of nickel, arsenic, and chromium. Metallomics 2012;4:619-27.

60. Steffen PA, Ringrose L. What are memories made of? How Polycomb and Trithorax proteins mediate epigenetic memory. Nat Rev Mol Cell Biol 2014;15:340-56.

61. Chanda S, Dasgupta UB, Guhamazumder D, Gupta M, Chaudhuri $\mathrm{U}$, et al. DNA hypermethylation of promoter of gene $\mathrm{p} 53$ and $\mathrm{p} 16$ in arsenic-exposed people with and without malignancy. Toxicol Sci 2006;89:431-7.

62. Suzuki T, Nohara K. Long-term arsenic exposure induces histone H3 Lys9 dimethylation without altering DNA methylation in the promoter region of $\mathrm{p} 16$ (INK4a) and down-regulates its expression in the liver of mice. J Appl Toxicol 2013;33:951-8.

63. Dong Z, Bode AM. The role of histone H3 phosphorylation (Ser10 and Ser28) in cell growth and cell transformation. Mol Carcinog 2006;45:416-21.

64. Strelkov IS, Davie JR. Ser-10 phosphorylation of histone H3 and immediate early gene expression in oncogene-transformed mouse fibroblasts. Cancer Res 2002;62.

65. Li J, Gorospe M, Barnes J, Liu Y. Tumor promoter arsenite stimulates histone $\mathrm{H} 3$ phosphoacetylation of proto-oncogenes $\mathrm{c}$-fos and c-jun chromatin in human diploid fibroblasts. J Biol Chem 2003;278:13183-91.

66. Kim HG, Shi C, Bode AM, Dong Z. p38alpha MAPK is required for arsenic-induced cell transformation. Mol Carcinog 2016;55:910-7.

67. Cheng MB, Zhang Y, Cao CY, Zhang WL, Zhang Y, et al. Specific phosphorylation of histone demethylase KDM3A determines target gene expression in response to heat shock. PLoS Biol 2014;12:e1002026.

68. Li B, Huang G, Zhang X, Li R, Wang J, et al. Increased phosphorylation of histone $\mathrm{H} 3$ at serine 10 is involved in Epstein-Barr virus latent membrane protein-1-induced 
carcinogenesis of nasopharyngeal carcinoma. BMC Cancer 2013;13:1-11.

69. Sassone-Corsi P, Mizzen CA, Cheung P, Crosio C, Monaco L, et al. Requirement of Rsk-2 for epidermal growth factor-activated phosphorylation of histone H3. Science 1999;285:886-91.

70. Winter S, Simboeck E, Fischle W, Zupkovitz G, Dohnal I, et al. 14-3-3 proteins recognize a histone code at histone $\mathrm{H} 3$ and are required for transcriptional activation. Embo J 2008;27:88-99.

71. Andrew AS, Mason RA, Memoli V, Duell EJ. Arsenic activates EGFR pathway signaling in the lung. Toxicol Sci 2009;109:350-7.

72. Yang W, Xia Y, Hawke D, Li X, Liang J, et al. PKM2 phosphorylates histone $\mathrm{H} 3$ and promotes gene transcription and tumorigenesis. Cell 2012;150:685-96.

73. Rea M, Jiang T, Eleazer R, Eckstein M, Marshall AG, et al. Quantitative mass spectrometry reveals changes in histone $\mathrm{H} 2 \mathrm{~B}$ variants as cells undergo inorganic arsenic-mediated cellular transformation. Mol Cell Proteomics 2016;15:2411-22.

74. Albig W, Trappe R, Kardalinou E, Eick S, Doenecke D. The Human H2A and H2B Histone Gene Complement. J Biol Chem 1999;380:7-18.

75. Zalensky AO, Siino JS, Gineitis AA, Zalenskaya IA, Tomilin NV, et al. Human testis/sperm-specific histone $\mathrm{H} 2 \mathrm{~B}$ (hTSH2B): molecular cloning and characterization. J Biol Chem 2002;277:43474-80.

76. Boulard M, Gautier T, Mbele GO, Gerson V, Hamiche A, et al. The NH2 Tail of the Novel Histone Variant H2BFWT Exhibits Properties Distinct from Conventional H2B with Respect to the Assembly of Mitotic Chromosomes. Mol Cell Biol 2006;26:1518-26.

77. Molden RC, Bhanu NV, LeRoy G, Arnaudo AM, Garcia BA. Multi-faceted quantitative proteomics analysis of histone $\mathrm{H} 2 \mathrm{~B}$ isoforms and their modifications. Epigenetics and Chromatin 2015;8:15.

78. Marashi F, Baumbach L, Rickles R, Sierra F, Stein JL, et al. Histone proteins in HeLa $\mathbf{S} \$\{3\}$ cells are synthesized in a cell cycle stage specific manner. Science 1982;215:683-5.

79. Jackson V, Chalkley R. Histone synthesis and deposition in the G1 and S phases of hepatoma tissue culture cells. Biochemistry 1985;24:6921-30.

80. Brocato J, Fang L, Chervona Y, Chen D, Kiok K, et al. Arsenic induces polyadenylation of canonical histone mRNA by downregulating stem-loop-binding protein gene expression. J Biol Chem 2014;289:31751-64.

81. Harris ME, Böhni R, Schneiderman MH, Ramamurthy L, Schümperli D, et al. Regulation of histone mRNA in the unperturbed cell cycle: evidence suggesting control at two posttranscriptional steps. Mol Cell Biol 1991;11:2416-24.

82. Kaufman PD, Kobayashi R, Kessler N, Stillman B. The p150 and p60 subunits of chromatin assemblyfactor I: A molecular link between newly synthesized histories and DNA replication. Cell 1995;81:1105-14.

83. Ray-Gallet D, Quivy J-P, Scamps C, Martini EMD, Lipinski M, et al. HIRA Is Critical for a Nucleosome Assembly Pathway Independent of DNA Synthesis. Mol Cell 2002;9:1091-100.

84. Elsaesser SJ, Goldberg AD, Allis CD. New functions for an old variant: no substitute for histone H3.3. Curr Opin Genet Dev 2010;20:110-7.

85. Szenker E, Ray-Gallet D, Almouzni G. The double face of the histone variant H3.3. Cell Res 2011;21:421-34.

86. Brocato J, Chen D, Liu J, Fang L, Jin C, et al. A potential new mechanism of arsenic carcinogenesis: depletion of stem-loop binding protein and increase in polyadenylated canonical histone H3.1 mRNA. Biol Trace Elem Res 2015;166:72-81.

87. Graves RA, Pandey NB, Chodchoy N, Marzluff WF. Translation is required for regulation of histone mRNA degradation. Cell 1987;48:615-26.

88. Kaygun H, Marzluff WF. Translation termination is involved in histone mRNA degradation when DNA replication is inhibited. Mol Cell Biol 2005;25:6879-88.

89. Downs JA, Lowndes NF, Jackson SP. A role for Saccharomyces cerevisiae histone H2A in DNA repair. Nature 2000;408:1001-4.

90. Redon C, Pilch DR, Rogakou EP, Orr AH, Lowndes NF, et al. Yeast histone $2 A$ serine 129 is essential for the efficient repair of checkpoint-blind DNA damage. EMBO Rep 2003;4:678-84.

91. Celeste A, Difilippantonio S, Difilippantonio MJ, Fernandez-Capetillo 0, Pilch DR, et al. H2AX Haploinsufficiency modifies genomic stability and tumor susceptibility. Cell 2003;114:371-83.

92. Fernandez-Capetillo O, Chen H-T, Celeste A, Ward I, Romanienko PJ, et al. DNA damage-induced G2-M checkpoint activation by histone H2AX and 53BP1. Nat Cell Biol 2002;4:993-7.

93. Bassing CH, Suh H, Ferguson DO, Chua KF, Manis J, et al. Histone H2AX: a dosage-dependent suppressor of oncogenic translocations and tumors. Cell 2003;114:359-70.

94. Weyemi U, Redon CE, Choudhuri R, Aziz T, Maeda D, et al. The histone variant H2A.X is a regulator of the epithelial-mesenchymal transition. Nat Commun. 2016;7:10711. doi: 10.1038/ ncomms10711.

95. Matthaios D, Hountis P, Karakitsos P, Bouros D, Kakolyris S. $\mathrm{H} 2 \mathrm{AX}$ a Promising Biomarker for Lung Cancer: A Review. Cancer Invest 2013;31:582-99.

96. Yang HD, Kim P-J, Eun JW, Shen Q, Kim HS, et al. Oncogenic potential of histone-variant H2A.Z.1 and its regulatory role in cell cycle and epithelial-mesenchymal transition in liver cancer. Oncotarget 2016;7:11412-23.

97. Dunican DS, McWilliam P, Tighe O, Parle-McDermott A, Croke DT. Gene expression differences between the microsatellite instability (MIN) and chromosomal instability (CIN) phenotypes in colorectal cancer revealed by high-density cDNA array hybridization. Oncogene 2002;21:3253-7.

98. Svotelis A, Gévry N, Grondin G, Gaudreau L. H2A.Z overexpression promotes cellular proliferation of breast cancer cells. Cell Cycle 2010;9:364-70.

99. Gévry N, Hardy S, Jacques P-É, Laflamme L, Svotelis A, et al. Histone H2A.Z is essential for estrogen receptor signaling. Gene Dev 2009;23:1522-33.

100. Zucchi I, Mento E, Kuznetsov VA, Scotti M, Valsecchi V, et al. Gene expression profiles of epithelial cells microscopically isolated from a breast-invasive ductal carcinoma and a nodal metastasis. Proc Natl Acad Sci USA 2004;101:18147-52.

101. Park Y-J, Dyer PN, Tremethick DJ, Luger K. A new fluorescence resonance energy transfer approach demonstrates that the histone variant $\mathrm{H} 2 \mathrm{AZ}$ stabilizes the histone octamer within the nucleosome. J Biol Chem 2004;279:24274-82.

102. Abbott DW, Ivanova VS, Wang X, Bonner WM, Ausió J. Characterization of the stability and folding of H2A.Z chromatin particles: implications for transcriptional activation. J Biol Chem 2001;276:41945-9.

103. Gévry N, Chan HM, Laflamme L, Livingston DM, Gaudreau L. p21 transcription is regulated by differential localization of histone H2A.Z. Gene Dev 2007;21:1869-81. 
104. Pehrson JR, Fried VA. MacroH2A, a core histone containing a large nonhistone region. Science 1992;257:1398-400.

105. Angelov D, Molla A, Perche P-Y, Hans F, Côté J, et al. The histone variant $\mathrm{MacroH} 2 \mathrm{~A}$ interferes with transcription factor binding and SWI/SNF nucleosome remodeling. Mol Cell 2003;11:1033-41.

106. Angelov D, Verdel A, An W, Bondarenko V, Hans F, et al. SWI/ SNF remodeling and $\mathrm{p} 300$-dependent transcription of histone variant H2ABbd nucleosomal arrays. EMBO J 2004;23:3815-24.

107. Chang EY, Ferreira H, Somers J, Nusinow DA, Owen-Hughes T, et al. MacroH2A allows ATP-dependent chromatin remodeling by SWI/SNF and ACF complexes but specifically reduces recruitment of SWI/SNF0. Biochemistry 2008;47:13726-32.

108. Doyen C-M, An W, Angelov D, Bondarenko V, Mietton F, et al. Mechanism of polymerase II transcription repression by the histone variant macroH2A. Mol Cell Biol 2006;26:1156-64.

109. Tomonaga T, Matsushita K, Yamaguchi S, Oohashi T, Shimada $\mathrm{H}$, et al. Overexpression and mistargeting of centromere protein-A in human primary colorectal cancer. Cancer Res 2003;63:3511-6.

110. Marsit C), Eddy K, Kelsey KT. MicroRNA responses to cellular stress. Cancer Res 2006;66:10843-48.

111. Bollati V, Marinelli B, Apostoli P, Bonzini M, Nordio F, et al. Exposure to metal-rich particulate matter modifies the expression of candidate microRNAs in peripheral blood leukocytes. Environ Health Perspect 2010;118:763-8.

112. Kong AP, Xiao K, Choi KC, Wang G, Chan MH, et al. Associations between microRNA (miR-21, 126, 155 and 221), albuminuria and heavy metals in Hong Kong Chinese adolescents. Clin Chim Acta 2012;413:1053-7.

113. Rager JE, Bailey KA, Smeester L, Miller SK, Parker JS, et al. Prenatal arsenic exposure and the epigenome: altered microRNAs associated with innate and adaptive immune signaling in newborn cord blood. Environ Mol Mutagen 2014;55:196-208.

114. Yu LJ, Luo YF, Liao B, Xie LJ, Chen L, et al. Comparative transcriptome analysis of transporters, phytohormone and lipid metabolism pathways in response to arsenic stress in rice (Oryza sativa). New Phytol 2012;195:97-112.

115. Srivastava S, Srivastava AK, Suprasanna P, D’Souza SF. Identification and profiling of arsenic stress-induced microRNAs in Brassica juncea. J Exp Bot 2013;64:303-15.

116. Luo F, Ji J, Liu Y, Xu Y, Zheng G, et al. MicroRNA-21, up-regulated by arsenite, directs the epithelial-mesenchymal transition and enhances the invasive potential of transformed human bronchial epithelial cells by targeting PDCD4. Toxicol Lett 2014;232:301-9.

117. Gao Y, Yin Y, Xing X, Zhao Z, Lu Y, et al. Arsenic-induced antiangiogenesis via miR-425-5p-regulated CCM3. Toxicol Lett 2016;254:22-31.

118. Venables JP. Aberrant and alternative splicing in cancer. Cancer Res 2004;64:7647-54.

119. Sveen A, Kilpinen S, Ruusulehto A, Lothe RA, Skotheim RI. Aberrant RNA splicing in cancer; expression changes and driver mutations of splicing factor genes. Oncogene 2016;35:2413-27.

120. Li XW, Shi BY, Yang QL, Wu J, Wu HM, et al. Epigenetic regulation of $\mathrm{CDH} 1$ exon 8 alternative splicing in gastric cancer. BMC Cancer 2015;15:954.

121. David CJ, Chen M, Assanah M, Canoll P, Manley JL. HnRNP proteins controlled by c-Myc deregulate pyruvate kinase mRNA splicing in cancer. Nature 2010;463:364-8.
122. Nowak DG, Woolard J, Amin EM, Konopatskaya O, Saleem MA, et al. Expression of pro- and anti-angiogenic isoforms of VEGF is differentially regulated by splicing and growth factors. J Cell Sci 2008;121:3487-95.

123. Brown RL, Reinke LM, Damerow MS, Perez D, Chodosh LA, et al. CD44 splice isoform switching in human and mouse epithelium is essential for epithelial-mesenchymal transition and breast cancer progression. J Clin Invest 2011;121:1064-74.

124. Xu Y, Gao XD, Lee JH, Huang H, Tan H, et al. Cell typerestricted activity of hnRNPM promotes breast cancer metastasis via regulating alternative splicing. Genes Dev 2014;28:1191-203.

125. Yearim A, Gelfman S, Shayevitch R, Melcer S, Glaich O, et al. HP1 is involved in regulating the global impact of DNA methylation on alternative splicing. Cell Rep 2015;10:1122-34.

126. Marina RJ, Sturgill D, Bailly MA, Thenoz M, Varma G, et al. TET-catalyzed oxidation of intragenic 5-methylcytosine regulates CTCF-dependent alternative splicing. EMBO J 2016;35:335-5.

127. Maunakea AK, Chepelev I, Cui K, Zhao K. Intragenic DNA methylation modulates alternative splicing by recruiting MeCP2 to promote exon recognition. Cell Res 2013;23:1256-69.

128. Maunakea AK, Nagarajan RP, Bilenky M, Ballinger TJ, D’Souza $C$, et al. Conserved role of intragenic DNA methylation in regulating alternative promoters. Nature 2010;466:253-7.

129. Pradeepa MM, Sutherland HG, Ule J, Grimes GR, Bickmore WA. Psip1/Ledgf $\mathrm{p} 52$ binds methylated histone H3K36 and splicing factors and contributes to the regulation of alternative splicing. PLoS Genet 2012;8:e1002717.

130. Luco RF, Pan Q, Tominaga K, Blencowe BJ, Pereira-Smith OM, et al. Regulation of alternative splicing by histone modifications. Science 2010;327:996-1000.

131. Curado J, lannone C, Tilgner H, Valcárcel J, Guigó R. Promoterlike epigenetic signatures in exons displaying cell type-specific splicing. Genome Biology 2015;16:236.

132. Agirre E, Bellora N, Allo M, Pages A, Bertucci P, et al. A chromatin code for alternative splicing involving a putative association between CTCF and HP1alpha proteins. BMC Biol 2015;13:31.

133. Riedmann C, Ma Y, Melikishvili M, Godfrey S, Zhang Z, et al. Inorganic Arsenic-induced cellular transformation is coupled with genome wide changes in chromatin structure, transcriptome and splicing patterns. BMC Genomics 2015;16:212.

134. Arita A, Niu J, Qu Q, Zhao N, Ruan Y, et al. Global levels of histone modifications in peripheral blood mononuclear cells of subjects with exposure to nickel. Environ Health Perspect 2012;120:198-203.

135. Arita A, Shamy MY, Chervona Y, Clancy HA, Sun H, et al. The effect of exposure to carcinogenic metals on histone tail modifications and gene expression in human subjects. J Trace Elem Med Biol 2012;26:174-8.

136. Zhang X, Wu J, Choiniere J, Yang Z, Huang Y, et al. Arsenic silences hepatic PDK4 expression through activation of histone H3K9 methylatransferase G9a. Toxicol Appl Pharmacol 2016;304:42-7.

137. Matveeva E, Maiorano J, Zhang Q, Eteleeb AM, Convertini P, et al. Involvement of PARP1 in the regulation of alternative splicing. Cell Discov 2016;2:15046.

138. Marina RJ, Oberdoerffer S. Epigenomics meets splicing through the TETs and CTCF. Cell Cycle 2016;15:1397-9. 
139. Guastafierro T, Catizone A, Calabrese R, Zampieri M, Martella 0 , et al. ADP-ribose polymer depletion leads to nuclear Ctcf re-localization and chromatin rearrangement(1). Biochem J 2013;449:623-30.

140. Ji Y, Tulin AV. Post-Transcriptional Regulation by Poly(ADPribosyl)ation of the RNA-Binding Proteins. Int J Mol Sci 2013;14:16168-83.

141. Ji Y, Tulin AV. Poly(ADP-ribosyl)ation of heterogeneous nuclear ribonucleoproteins modulates splicing. Nucleic Acids Res 2009;37:3501-13.

142. Stueckle TA, Lu Y, Davis ME, Wang L, Jiang B-H, et al. Chronic occupational exposure to arsenic induces carcinogenic gene signaling networks and neoplastic transformation in human lung epithelial cells. Toxicol Appl Pharm 2012;261:204-16.

143. Malanga M, Czubaty A, Girstun A, Staron K, Althaus FR. Poly(ADP-ribose) binds to the splicing factor ASF/SF2 and regulates its phosphorylation by DNA topoisomerase I. J Biol Chem 2008;283:19991-8.

144. Nalabothula N, McVicker G, Maiorano J, Martin R, Pritchard JK, et al. The chromatin architectural proteins HMGD1 and H1 bind reciprocally and have opposite effects on chromatin structure and gene regulation. BMC Genomics 2014;15:92.

145. Zhou X, Sun X, Cooper KL, Wang F, Liu KJ, et al. Arsenite interacts selectively with zinc finger proteins containing $\mathrm{C} 3 \mathrm{H} 1$ or $\mathrm{C} 4$ motifs. J Biol Chem 2011;286:22855-63.

146. Ding W, Liu W, Cooper KL, Qin XJ, de Souza Bergo PL, et al. Inhibition of poly(ADP-ribose) polymerase-1 by arsenite interferes with repair of oxidative DNA damage. J Biol Chem 2009;284:6809-17.

147. Sun X, Zhou X, Du L, Liu W, Liu Y, et al. Arsenite bindinginduced zinc loss from PARP-1 is equivalent to zinc deficiency in reducing PARP-1 activity, leading to inhibition of DNA repair. Toxicol Appl Pharmacol 2014;274:313-8.

148. Liu S, Jiang J, Li L, Amato NJ, Wang Z, et al. Arsenite targets the zinc finger domains of tet proteins and inhibits tetmediated oxidation of 5-methylcytosine. Environ Sci Technol 2015;49:11923-31.

149. Wang F, Shi Y, Yadav S, Wang H. p52-Bcl3 complex promotes cyclin D1 expression in BEAS-2B cells in response to low concentration arsenite. Toxicology 2010;273:12-8.

150. Best A, Dagliesh C, Ehrmann I, Kheirollahi-Kouhestani M, Tyson-Capper A, et al. Expression of Tra2 beta in Cancer Cells as a Potential Contributory Factor to Neoplasia and Metastasis. Int J Cell Biol 2013;2013:843781.

151. Das S, Anczukow O, Akerman M, Krainer AR. Oncogenic splicing factor SRSF1 is a critical transcriptional target of MYC. Cell Rep 2012;1:110-7.

152. Ruiz-Ramos R, Lopez-Carrillo L, Albores A, Hernandez-Ramirez RU, Cebrian ME. Sodium arsenite alters cell cycle and MTHFR, MT1/2, and c-Myc protein levels in MCF-7 cells. Toxicol Appl Pharmacol 2009;241:269-74.

153. Koh CM, Bezzi M, Low DH, Ang WX, Teo SX, et al. MYC regulates the core pre-mRNA splicing machinery as an essential step in lymphomagenesis. Nature 2015;523:96-100.

154. Grosso AR, Gomes AQ, Barbosa-Morais NL, Caldeira S, Thorne NP, et al. Tissue-specific splicing factor gene expression signatures. Nucleic Acids Res 2008;36:4823-32.

155. Yeo G, Holste D, Kreiman G, Burge CB. Variation in alternative splicing across human tissues. Genome Biol 2004;5:R74.

156. Fu XD, Ares M, Jr. Context-dependent control of alternative splicing by RNA-binding proteins. Nat Rev Genet 2014;15:689-701. 